\title{
GRN wt Allele
}

National Cancer Institute

\section{Source}

National Cancer Institute. GRN wt Allele. NCI Thesaurus. Code C101402.

Human GRN wild-type allele is located in the vicinity of $17 q 21.32$ and is approximately 8 $\mathrm{kb}$ in length. This allele, which encodes granulins protein, plays a role in signaling. Mutation of the gene is associated with ubiquitin-positive frontotemporal dementia. 